\title{
PEMANTAPAN DAN PENANAMAN NILAI DAN SIKAP ANTI KORUPSI PADA ANAK-ANAK DENGAN PERMAINAN YANG MENYENANGKAN (PERMAINAN SEMAI DARI “GERAKAN SPAK”-KPK)
} Nurul Badriyah ${ }^{1}$

\author{
Faultas Ekonomi dan Bisnis, Universitas Brawijaya Malang ${ }^{1}$
}

\begin{abstract}
Abstrak
Ketika anak-anak sudah memahami melalui permainan, mereka kemudian akan tumbuh dengan nilai-nilai tersebut. Dengan permainan yang menyenangkan, anak-anak diharapkan akan tumbuh menjadi pribadi yang berkarater mulia dan berintegritas. Salah satu upaya KPK dalam tindakan pencegahan korupsi adalah melalui permainan SEMAI. Permainan Sembilan Nilai (SEMAI) antikorupsi yang merupakan salah satu permainan yang dikenalkan oleh Gerakan "Saya Perempuan Anti Korupsi" (SPAK) dan KPK adalah jenis permainan yang ditujukan untuk anak-anak sebagai bagian dari gerakan untuk mencoba menanamkan nilai-nilai antikorupsi kepada anak-anak. Pengabdian ini dilakukan pada siswa di SD Negeri Percobaan 1 Kota Malang kelas 3. Secara khusus, dampak positif terbentuk pada siswa SD Negeri Percobaan 1 Kota Malang kelas 3 sebagai objek yang dituju pada kegiatan pengabdian kepada masyarakat ini. Perubahan perilaku ini terlihat dalam kemandirian dalam Jum'at Bersih, penghematan untuk konsumsi di sekolah, peningkatan amal yang dilaksanakan dalam Jum'at Berbagi, kedisiplinan yang terlihat dalam penurunan jumlah siswa yang terlambat, serta kepercayaan diri yang terlihat dalam kegiatan ulangan. Kegiatan ini merupakan perwujudan dari upaya ikut serta dalam pencegahan tindakan korupsi dan meningkatkan kepekaan terhadap sikap dan nilai anti korupsi sejak dini, sehingga perlu dilaksanakan kegiatan pemantapan dan sosialisasi sikap dan nilai ini terhadap anakanak sejak dini.
\end{abstract}

Kata kunci: Anti korupsi, SEMAI, internalisasi nilai

\section{PENDAHULUAN}

Telah lama Indonesia dikenal sebagai negara yang korup. Kejahatan korupsi di Indonesia bahkan telah meluas sebagai penyakit yang akut, yang tidak saja menyerang bagian tertentu dari lapisan masyarakat, tetapi telah menyebar ke seluruh ruang dan sendi-sendi kehidupan dan segala level masyarakat. Bukan sesuatu yang mengherankan jika kemudian masalah korupsi di Indonesia terus menjadi berita utama (headline) hampir setiap hari di media di Indonesia.

Sebuah institusi non-partisan, bernama Transparancy International, yang berbasis di Berlin, Jerman telah menerbitkan Indeks Persepsi Korupsi tahunan (berdasarkan polling) yang menilai "sejauh mana korupsi dianggap terjadi di kalangan pejabat publik dan politisi" di semua negara seluruh dunia. Indeks Persepsi Korupsi Tahunan ini menggunakan skala dari 1 sampai 10. Semakin tinggi hasilnya, semakin sedikit (dianggap) korupsi yang terjadi.

Angka-angka yang menunjukkan tingkat persepsi korupsi dalam jajak pendapat dari negara tertentu dapat dipandang sebagai cerminan masyarakat yang umumnya memiliki pemahaman yang baik tentang apa yang terjadi di negeranya. Sehingga, tentu saja angka-angka ini mengindikasikan informasi korupsi yang relevan. Catatan mengenai Indeks Persepsi Korupsi 2015 ini dapat diamati pada tabel 1 di bawah ini:

\footnotetext{
${ }^{1}$ nurulbayhaqi@ub.ac.id
} 
Tabel 1

Perbandingan Indeks Persepsi Korupsi

Indonesia dan Negara Lain, 2015:

\begin{tabular}{|l|l|l|}
\hline NO & NAMA NEGARA & $\begin{array}{l}\text { INDEKS } \\
\text { KORUPSI }\end{array}$ \\
\hline 1 & Denmark & 9,1 \\
\hline 2 & Finland & 9 \\
\hline 3 & Swedia & 8,9 \\
\hline 4 & Selandia Baru & 8,8 \\
\hline 5 & Belanda & 8,7 \\
\hline 6 & Norwegia & 8,7 \\
\hline 7 & Indonesia & 3,6 \\
\hline
\end{tabular}

Sumber: Transparency International, 2015

Berdasarkan data tersebut, negara dengan peringkat teratas adalah Denmark, Finlandia, Swedia, Selandia Baru, Belanda, dan Norwegia. Sedangkan negara-negara dengan peringkat terbawah menurut data Transparency International Indonesia, berturut-turut adalah Sudan Selatan, Sudan, Afganistan, Korea Utara, dan Somalia.

Hasil rilis mengenai kondisi persepsi korupsi tersebut mengindikasikan mengenai agenda usaha keras dan masif yang harus dilakukan sebagai upaya untuk mengatasi situasi akut tindakan korupsi di Indonesia. Meskipun Catatan mengenai capaian hasil tahun-tahun sebelumnya tentang indeks korupsi menunjukkan tren yang positif, namun masih jauh dari angka ideal. Dalam 10 tahun terakhir, pergerakan perbaikan angka indeks tersebut maksimal hanya berubah 1 poin, bahkan pada beberapa tahun perubahannya hanya berkisar di poin desimal di belakang koma. Berikut ini data perubahan indeks korupsi tersebut dalam 10 tahun terakhir.

Tabel 2. PERBANDINGAN INDEKS PERSEPSI KORUPSI INDONESIA 2005-2015

\begin{tabular}{|l|l|}
\hline Tahun & Angka Indeks \\
\hline 2005 & 2.2 \\
\hline 2006 & 2.4 \\
\hline 2007 & 2.3 \\
\hline 2008 & 2.6 \\
\hline 2010 & 2.8 \\
\hline 2011 & 3.0 \\
\hline 2012 & 3.2 \\
\hline 2013 & 3.2 \\
\hline 2014 & 3.4 \\
\hline 2015 & 3,6 \\
\hline
\end{tabular}

Sumber: Transparency International, 2015

Harus diakui bahwa semua yang telah dilakukan belum mampu menghilangkan korupsi di Indonesia. Oleh karena itu, diperlukan upaya-upaya penguatan yang lebih besar lagi untuk terus mempertahankan konsistensi perlawanan terhadap korupsi. Perlawanan terhadap korupsi melalui penindakan adalah upaya yang terbatas, hanya bisa dilakukan oleh para penegak hukum. Sementara perlawanan melalui pencegahan bisa dan perlu partisipasi dari semua kekuatan bangsa, sebagaimana telah disebutkan di atas. Salah satu kekuatan yang sudah lama dikenali dan sangat diperhitungkan adalah kekuatan para perempuan Indonesia, baik melalui perannya sebagai ibu dan sebagai istri maupun perannya dalam organisasi wanita atau perannya sebagai profesional. Sebagai istri dan sebagai ibu, perempuan adalah tokoh sentral dalam keluarga yang memberi andil sangat besar terhadap arah perkembangan suami maupun anak-anak. Hal inilah yang menjadi perhatian bagi Komisi Pemberantasan Korupsi (KPK) dan AIPJ (Australia Indonesia Partnership for Justice). AIPJ adalah salah satu program Australian Aid untuk 
penegakan hukum dan keadilan. KPK dan AIPJ percaya bahwa, kekuatan perempuan Indonesia akan memberikan kontribusi yang luar biasa bagi upaya perlawanan terhadap korupsi khususnya dalam hal pencegahan.

KPK bersama AIPJ kemudian mendorong ke wilayah yang lebih luas lagi menjadi gerakan nasional perempuan melawan korupsi, melalui jalur pencegahan yang diluncurkan bersamaan dengan peringatan Hari Kartini pada 22 April 2014 lalu. Peluncuran gerakan ini bertujuan untuk melibatkan lebih banyak perempuan dan organisasi perempuan untuk ikut berpartisipasi dengan melindungi diri dari korupsi dan menjadi agen pencegahan korupsi dengan cara menyebarluaskan pengetahuan modus-modus dan peluang-peluang yang berpotensi korupsi serta konsekuensi hukumnya.

Hal ini didapat melalui perangkat alat bantu pendidikan anti korupsi berupa $D V D$, buku dan permainan yang dibagikan kepada para perempuan untuk digunakan dalam melakukan pendidikan anti korupsi di komunitasnya masing-masing dan menciptakan gelombang besar pencegahan korupsi dengan perempuan sebagai aktor utama agen pencegahan. Beberapa peserta dari berbagai rangkaian kegiatan di atas juga telah melakukan sendiri kegiatan sosialisasi atau pendidikan anti korupsi baik di dalam lingkungan keluarganya masing-masing, masyarakat di lingkungan sekitar, komunitasnya maupun dalam lingkup profesinya.

Pada September 2015, telah dilaksanakan ToT SPAK di Kota Malang, untuk beberapa peserta, dari berbagai latar belakang dan profesi yang kemudian melahirkan diaspora agen-agen pelaksana gerakan SPAK. Tujuan dari ToT ini sendiri ini adalah menciptakan pool of trainers/facilitator yang memahami konsep Gerakan "Saya, Perempuan Anti Korupsi” secara mendalam dan terampil melakukan pendidikan anti korupsi (termasuk menggunakan alat bantu) agar menjadi focal point agen anti korupsi dalam tiap komunitas di Kota Malang. Melalui TOT ini diharapkan para trainer/fasilitator ini nantinya juga mampu menyebarluaskan sendiri gerakan kepada lebih banyak orang tanpa harus tergantung pada arahan dari KPK maupun dukungan AIPJ. Peserta ToT ini, terdiri dari Ibu-ibu Dharmawanita, BKOW, CSO, akademisi dan PNS dari kabupaten-kabupaten/Kota-kota di Jawa Timur.

Sebagaimana desain kegiatan ini, untuk memastikan keberlanjutan dari program ini dan memperkuat hubungan antara peserta pelatihan dengan KPK - maka telah pula dilakukan post training program pada Desember 2015. Program ini bertujuan diantaranya untuk mengetahui sejauh mana para peserta khususnya yang tinggal di wilayah kabupaten/kota menindaklanjuti pengetahuan dan keterampilan yang mereka peroleh di TOT Gerakan "Saya, Perempuan Anti Korupsi". Selain itu perlu juga diketahui tingkat penerimaan dan komitmen targeted stakeholder di daerah di luar ibukota provinsi untuk berpartisipasi dalam pencegahan korupsi di keluarga, lingkungan sekitar dan komunitasnya masing-masing. Sebagai lanjutan dari pelaksanaan 2 TOT SPAK tersebut, serta menindaklanjuti pengetahuan dan keterampilan yang telah diperoleh dari TOT Gerakan "Saya, Perempuan Anti Korupsi" pengabdi yang merupakan salah satu agen gerakan ini terdorong untuk melakukan pengabdian masyarakat berupa kegiatan "Pemantapan Dan Penanaman Nilai Dan Sikap Anti Korupsi Pada Anak-Anak Dengan Permainan Yang Menyenangkan (Permainan Semai Dan Majo Dari "Gerakan SPAK"-KPK)". Kegaiatan ini sekaligus dimaksudkan sebagai penyebarluasan gerakan anti korupsi, sesuai dengan komitmen agen yang sejalan dengan harapan KPK-AIPJ bahwa setelah kegiatan TOT SPAK dan POST TRAINING SPAK, para agen agar menyebarluaskan sendiri gerakan kepada lebih banyak orang tanpa harus tergantung pada arahan dari KPK maupun dukungan AIPJ.

\section{KAJIAN PUSTAKA}

\section{Konsep Pemberdayaan, Peningkatan Kemandirian Masyarakat dan Pencegahan Korupsi}

Pemberdayaan masyarakat adalah proses capaian masyarakat untuk mendapatkan surplus value sebagai hak manusia yang terlibat dalam interaksi bersama. Menurut Afshar (dalam Hancock, 2000) pada waktu yang berbeda dalam sejarah, pemberdayaan mempunyai makna yang berbeda. Hal ini disebabkan oleh budaya dan geografi setempat. Pemberdayaan perlu dirancang sedemikian rupa sehingga tidak menjadi sesuatu yang dikerjakan pada perempuan atau untuk perempuan. Pemberdayaan harus datang dari perempuan sendiri dan menjadi sesuatu yang mereka miliki sendiri. Jadi, perempuan harus memberdayakan diri mereka sendiri dengan sedikit mungkin bantuan dari luar.

Tujuan dari pemberdayaan adalah untuk membentuk individu dan masyarakat menjadi lebih mandiri. Dimana kemandirian tersebut meliputi kemandirian berpikir, bertindak, dan mengendalikan apa yang mereka lakukan tersebut. Kemandirian masyarakat adalah suatu kondisi yang dialami masyarakat yang ditandai oleh kemampuan untuk memikirkan, memutuskan serta melakukan sesuatu yang dipandang 
tepat demi mencapai pemecahan masalah-masalah yang dihadapi dengan mempergunakan daya kemampuan yang terdiri kemampuan kognitif, konatif, psikomotorik, afektif, dengan pengerahan sumber daya yang dimiliki oleh lingkungan internal masyarakat tersebut.

Untuk mencapai kemandirian masyarakat diperlukan sebuah proses. Melalui proses belajar maka masyarakat secara bertahap akan memperoleh kemampuan. Dengan proses belajar tersebut akan diperoleh kemampuan/daya dari waktu ke waktu. Yang diharapkan dari adanya pemberdayaan adalah untuk mewujudkan komunitas yang baik, masyarakat yang ideal. Menurut Montagu \& Matson dalam Suprijatna (Suprijatna, Tjahja, 2000:13) dalam the Dumanization of Man, yang mengusulkan konsep The Good Community and Competency yang meliputi sembilan konsep komunitas dan empat komponen kompetensi masyarakat. The Good Community and Competency adalah :

1) Setiap anggota masyarakat berinteraksi satu sama lain berdasarkan hubungan pribadi, adanya kelompok juga kelompok primer.

2) Komunitas memiliki otonomi yaitu kewenangan dan kemampuan untuk mengurus kepentingannya sendiri secara bertanggung jawab.

3) Memiliki vialibilitas yaitu kemampuan untuk memecahkan masalah sendiri.

4) Distribusi kekuasaan merata sehingga setiap orang berkesempatan riil, bebas memiliki dan menyatakan kehendak.

5) Kesempatan setiap anggota masyaakat untuk berpartisipasi aktif untuk kepentingan bersama.

6) Komunitas memberi makna kepada anggota.

7) Adanya heterogenitas dan beda pendapat.

8)Pelayanan masyarakat ditempatkan sedekat dan secepat kepada yang berkepentingan.

9) Adanya konflik dan managing konflik. berikut :

Sedangkan untuk melengkapi sebuah komunitas yang baik perlu ditambahkan kompetensi sebagi

1) Mampu mengidentifikasikan masalah dan kebutuhan komunitas.

2) Mampu mencapai kesempatan tentang sasaran yang hendak dicapai dan skala prioritas.

3) Mampu menemukan dan menyepakati cara dan alat mencapai sasaran yang telah disetujui.

4) Mampu Bekerjasama rasional dalam bertindak mencapai tujuan.

\section{Permainan pada Anak-Anak; Anatomi, Fungsi, dan Faedah}

Aktivitas bermain, bagi anak adalah belajar. Dalam kegiatan dengan pembelajaran itu, anak akan mendapat pengalaman baru, menjadi diri sendiri, merangsang kecerdasan otak, dan lain lain. Untuk permainan yang bisa dilakukan anak terdapat banyak jenis permainan dengan kekhususan sifat masingmasing permainan tersebut, misalnya permainan sensorimotor, yaitu permainan yang menggunakan semua indera. Ada pula yang disebut permainan simbolis, yaitu pemainan yang biasa dilakukan anak anak dengan berpura pura, atau permainan konstruktif, yaitu permainan yang menggabungkan sensorimotor dan simbolis, permainan sosial yaitu permainan yang dilakukan di mana anak berinteraksi sosial dengan teman mainnya, dan juga permainan kompetisi yang melibatkan aturan aturan dalam bermain.

Terdapat banyak sekali manfaat permainan ini bagi anak-anak. Dari yang banyak tersebut, para ahli psikologi anak bersepakat untuk beberapa fungsi dan manfaat bermain bagi anak, seperti tersebut di bawah ini:

\section{Fungsi dan Manfaat Bermain Untuk Kemampuan Intelektual}

Dalam permainan ini, anak dapat merangsang kemampuan kognitif mereka. Dalam permainan sensorimortor, anak dapat mengenal permukaan lembut, halus, kasar, dll. Sehingga dapat meningkatkan kemampuan abstraksi (imajinasi, fantasi). Selanjutnya, anak juga dapat membangun struktur kognitif di mana anak dapat memperoleh informasi lebih banyak, sehingga pengetahuan dan pengalamannya lebih mendalam.

Fungsi Bermain Sebagai Labratorium Bahasa 
Didalam bermain anak akan bercakap dengan temannya. Sehingga, dalam tahapan selanjutnya mereka dapat menemukan atau menambah kosakata baru dan kosakata yang mereka miliki pun tentu akan bertambah.

\section{Fungsi Bermain Sebagai Perkembangan Sosial}

Ketika bermain anak akan memperhatikan cara pandang teman mainya sehingga akan mengurangi keegoisan pada diri si anak. Permainan dapat membuat si anak untuk mengembangkan kemampuan komunikasi mereka.

\section{Fungsi Bermain Untuk Perkembangan Emosi}

Dalam bermain si anak akan melampiaskan emosi dan relaksasinya. Karena, dalam bermain si anak dapat mengeksperikan kegembiraan, tawa mungkin juga kadang ada sedikit kemarahan yang diakibatkan suatu hal.

\section{Fungsi Bermain Untuk Perkembangan Fisik}

Dengan bermain, si anak dapat mengembangkan pengindraan mereka dan mengenal berbagai hal yang ia lihat, sentuh, cium, dengar dan lainnya. Juga, dalam bermain si anak dapat menyalurkan energi fisik yang terpendam.

\section{Fungsi Bermain Untuk Kreatifitas}

Dalam bermain anak dapat berimajinasi sehingga mereka dapat mengembangkan kreatifitasnya. Kesempatan berpikir antara batasan batasan dunia nyata. ketika bermain, menjadikan si anak dapat berpikir secara kreatif yang tentunya akan sangat berguna bagi kehidupannya sehari hari.

\section{Permainan SEMAI (SPAK-KPK) dan Upaya Pencegahan Korupsi}

Permainan Sembilan Nilai (SEMAI) antikorupsi yang merupakan salah satu permainan yang dikenalkan oleh Gerakan "Saya Perempuan Anti Korupsi" (SPAK) dan KPK adalah jenis permainan yang ditujukan untuk anak-anak sebagai bagian dari gerakan untuk mencoba menanamkan nilai-nilai antikorupsi kepada anak-anak. Sembilan nilai ini diantaranya, kejujuran, kepedulian, kegigihan, keadilan, tanggung jawab, kerjasama, sederhana, keberanian dan kedisiplinan.

Melalui permainan SEMAI ini, diharapkan bisa dilakukan upaya penanaman nilai-nilai antikorupsi pada anak sedini mungkin. Anak-anak kemudian bisa memahami dan mempraktikkan sedini mungkin sembilan nilai-nilai itu. Misalnya saja mencontek dan memberi contekan pada temannya, hal itu bertentangan dengan nilai kejujuran.

Kegiatan seperti dalam permainan SEMAI ini merupakan salah satu upaya KPK dalam tindakan pencegahan korupsi. Ketika anak-anak sudah memahami melalui permainan, mereka kemudian akan tumbuh dengan nilai-nilai tersebut. Dengan permainan yang menyenangkan, anak-anak diharapkan akan tumbuh menjadi pribadi yang berkarater mulia dan berintegritas. Nilai-nilai ini jika diajarkan kepada anak sejak dini, diyakini akan membawa manfaat hingga mereka tumbuh besar dan ketika mereka menjadi pejabat publik atau menjalankan profesi lainnya. Permainan SEMAI, merupakan salah satu dari empat alat bantu yang digunakan dalam program "Saya, Perempuan Anti Korupsi” (SPAK), khususnya untuk segmen anak.

SEMAI sendiri diluncurkan pertama kali, bersamaan dengan peringatan setahun program SPAK pada 21 April 2015 di Jakarta. Permainan ini bisa dimainkan berdua atau berkelompok. Terdiri dari papan permainan, kartu putih berisi situasi, dan kartu merah berisi pertanyaan untuk hukuman. Pada papan permainan, terdiri dari dua bagian. Masing-masing bagian terdiri dari 9 kotak bergambar yang bertuliskan nilai-nilai antikorupsi tersebut.

Adapun cara atau atauran mainnya, kedua pihak yang menjadi peserta didampingi oleh fasilitator yang bertugas memberikan pertanyaan dan menentukan benar-salahnya jawaban peserta. Setelah fasilitator menentukan siapa peserta yang memulai terlebih dahulu, maka ia harus mengambil satu kartu putih, lalu membacakan dengan saksama situasi yang dideskripsikan dalam kartu tersebut. Kemudian, ia harus menentukan situasi tersebut, masuk ke dalam kelompok nilai antikorupsi yang mana; kejujuran, kepedulian; kemandirian dan seterusnya, lalu meletakkan kartu tersebut ke nilai antikorupsi di atas papan.

Sementara itu, pemain lawan harus memberikan penilaian disertai alasan, apakah jawaban tersebut benar atau salah. Fasilitator akan memimpin diskusi tersebut dan memberikan keputusan. Bila jawaban tersebut salah, peserta tersebut harus mengambil kartu merah dan menjawab pertanyaan atau melaksanakan 
perintah yang tertera di dalamnya. Begitu seterusnya bergiliran. Peserta atau kelompok yang menang, adalah mereka yang paling banyak menempatkan kartu putih dan paling sedikit mengambil kartu merah.

Dengan permainan yang berbasis pembiasaan pada situasi antikorupsi, diharapkan nilai-nilai tersebut bisa dengan mudah dicerna, dipahami dan ditiru. Sehingga internalisasi nilai, dilakukan secara alamiah dan menyenangkan. Seperti halnya internalisasi nilai dan pembentukan karakter, mungkin manfaatnya tidak segera dirasakan, tetapi hal yang harus diyakini adalah permainan ini akan memberikan pengaruh positif pada pribadi anak-anak di masa depan.

\section{METODOLOGI}

Metode kegiatan pemantapan dan pananaman nilai-nilai anti korupsi dengan metode permainan yang menyenangkan ini dilakukan dengan program bermain di sekolah, yang dirangkai pula dengan penyampaian materi mengenai korupsi, bentuk-bentuknya, bahaya yang ditimbulkan, upaya penanganan dan pencegahan, serta edukasi mengenai nilai-nilai yang merupakan sikap moral yang bisa dikembangkan sehari-hari. Peserta yang disasar dalam kegiatan pengabdian ini adalah siswa-siswi SD. Pemilihan kategori peserta dalam kegiatan ini disesuaikan tujuan pengabdian, yaitu anak-anak, dengan memperhatikan kesesuaian usia yang sekiranya sudah mampu untuk menerima materi atau penjelasan mengenai tema korupsi. Pengabdian ini dilakukan pada siswa di SD Negeri Percobaan 1 Kota Malang kelas 3.

Pelaksanaan "secara fisik" kegiatan ini dilakukan selama dua hari, yaitu hari Jumat-Sabtu, 28-29 Oktober 2016. Sedangkan pelaksanaan "non fisik" berupa pengamatan perubahan perilaku anak-anak, dilakukan selama kurang lebih satu bulan, dengan melibatkan peran serta guru kelas dalam tindakan pengamatannya. Setiap minggu, tim pengabdi melakukan upaya dialog dengan guru kelas yang sehari-hari berinteraksi dengan anak-anak tersebut, dalam rangka mengetahui perkembangan perilaku setelah dikenalkan dengan pengetahuan tentang korupsi dan melaksanakan permainan SEMAI yang menyenangkan. Selanjutnya, anak-anak yang sudah mengenal teknik permainan, memahami nilai-nilai yang diperkenalkan dalam permainan ini, dan bahkan mengapliasikan nilai-nilai tersebut dalam kehidupan sehari-hari, selanjutnya akan menyebar dalam komunitasnya masing-masing dan akan dikoordinasikan kembali untuk penyebarluasan nilai dan sikap antikorupsi ini. Pada gilirannya sehingga nilai dan sikap antikorupsi ini akan dikenal secara meluas oleh anak-anak dan mendukung gerakan yang lebih masif. Adapun materi dari kegiatan permainan SEMAI yang dilaksanakan adalah sebagai berikut:

\begin{tabular}{|l|l|l|}
\hline No & Materi Kegiatan & Pemateri \\
\hline 1 & Pembukaan & Tim Pengabdi \\
\hline 2 & $\begin{array}{l}\text { Penjelasan mengenai Korupsi, } \\
\text { korupsi di Indonesia dan } \\
\text { dampaknya }\end{array}$ & $\begin{array}{l}\text { Dra. Syahrotsah Rahmaniah, M.Si (tokoh Public Speaking, } \\
\text { Anchor Radio Madinah FM, aktivis perempuan kota Malang } \\
\text { dan agen SPAK Kota Malang) }\end{array}$ \\
\hline 3 & $\begin{array}{l}\text { Penjelasan niali dan sikap anti } \\
\text { korupsi }\end{array}$ & $\begin{array}{l}\text { Aini Chikmawati, S. Pi (Penggerak PKK Kota Malang, agen } \\
\text { SPAK Kota Malang) }\end{array}$ \\
\hline 4 & Bermain "Semai” & Tim Pengabdi \\
\hline 5 & Pengamatan dan Pemantauan & Tim Pengabdi \\
\hline
\end{tabular}

Sedangkan Jadwal Kerja Kegiatan pengabdian pada masyarakat ini dirancang sebagaimana pada tabel berikut:

\begin{tabular}{|l|l|l|l|l|l|l|l|}
\hline No & JENIS KEGIATAN & \multicolumn{3}{|l|}{ MINGGU KE } & $\mathbf{3}$ & $\mathbf{6}$ \\
\hline & & $\mathbf{1}$ & $\mathbf{2}$ & $\mathbf{3}$ & $\mathbf{4}$ & $\mathbf{5}$ & $\mathbf{6}$ \\
\hline 1 & Perijinan Kegiatan & & & & & & \\
\hline 2 & Pelaksanaan Kegiatan Pelatihan & & & & & & \\
\hline 3 & Evaluasi Kegiatan & & & & & & \\
\hline 4 & Penyusunan Laporan & & & & & & \\
\hline 7 & Penyerahan Laporan & & & & & & \\
\hline
\end{tabular}

\section{HASIL DAN PEMBAHASAN}

\section{Gambaran Pelaksanaan Kegiatan Fisik Permainan SEMAI (SPAK-KPK)}

Dalam kegiatan pemantapan dan pananaman nilai-nilai anti korupsi bersama siswa di SD Negeri

Percobaan 1 Kota Malang kelas 3, diharapkan dapat menindaklanjuti salah satu focal point komunitas perempuan dari kalangan akademisi, memperdalam keterlibatan pengabdi dalam gerakan anti korupsi 
sehingga mencakup lebih banyak sasaran target dalam penyebaran gerakan anti korupsi kepada komunitasnya masing-masing dan wujud dorongan komitmen untuk melakukan tindak lanjut TOT SPAK, serta mengaplikasikan pengetahuan dan ketrampilan yang dimiliki agen SPAK untuk membentuk gerakan anti korupsi yang nyata. Permainan ini merupakan salah satu upaya preventif terhadap tindakan korupsi sejak mula diperlukan penanaman sikap dan nilai anti korupsi yang dibentuk sejak usia dini. Selain itu, permainan ini adalah salah satu upaya ikut serta dalam pencegahan tindakan korupsi dan SEMAI ini adalah permainan kartu yang merangkum sembilan nilai (semai) yang merupakan nilai inti anti korupsi yang selanjutnya dapat dikembangkan untuk pembentukan sikap anti korupsi.

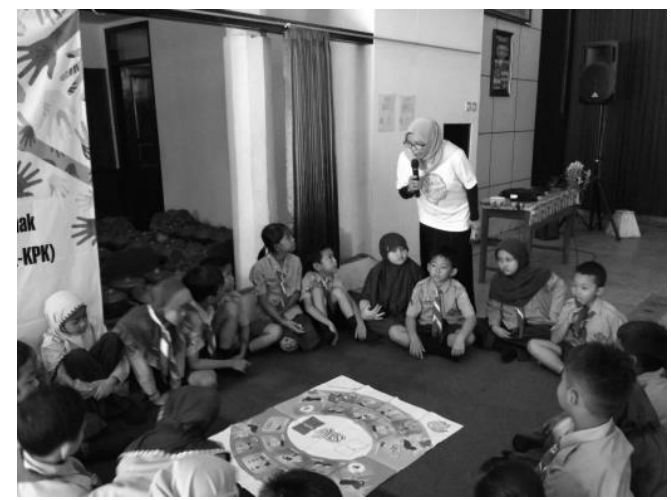

\section{Gambar 1. Menjelaskan aturan main permainan SEMAI}

Pelaksanaan "secara fisik" kegiatan ini dilakukan selama dua hari, yaitu hari Jumat-Sabtu, 28-29 Oktober 2016. Permainan ini dimainkan secara berkelompok bersama para siswa kelas 3. Dengan menggunakan alat-alat bermain berupa papan permainan, kartu putih berisi situasi, dan kartu merah berisi pertanyaan untuk hukuman, para siswa bermain dengan bimbingan fasilitator. Penjelasan yang diberikan adalah pada papan permainan, terdiri dari dua bagian. Masing-masing bagian terdiri dari 9 kotak bergambar yang bertuliskan nilai-nilai antikorupsi tersebut, yaitu kejujuran, kepedulian, kegigihan, keadilan, tanggung jawab, kerjasama, sederhana, keberanian dan kedisiplinan.

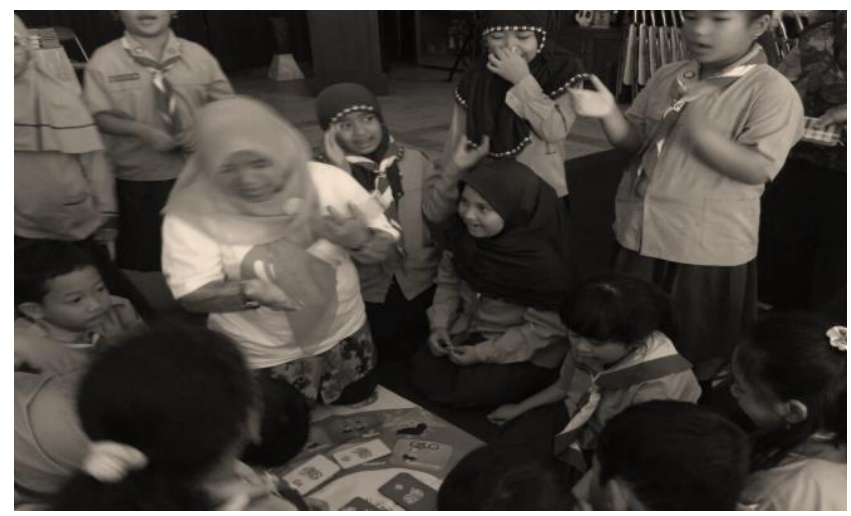

Gambar 2 Keriangan sepanjang permainan SEMAI 
Para siswa kemudian mendengarkan dengan seksama instruksi dari fasilitator, dimana kedua tim yang menjadi peserta didampingi oleh fasilitator yang bertugas memberikan pertanyaan dan menentukan benar-salahnya jawaban peserta. Setelah itu, peserta yang memulai terlebih dahulu ditentukan oleh fasilitator. Peserta yang memulai terlebih dahulu kemudian mengambil satu kartu putih, kemudian membacakan dengan saksama situasi yang dideskripsikan di dalam kartu tersebut. Kemudian, siswa tersebut menentukan apakah situasi tersebut masuk ke dalam kelompok nilai antikorupsi kejujuran, kepedulian, kegigihan, keadilan, tanggung jawab, kerjasama, sederhana, keberanian atau kedisiplinan.

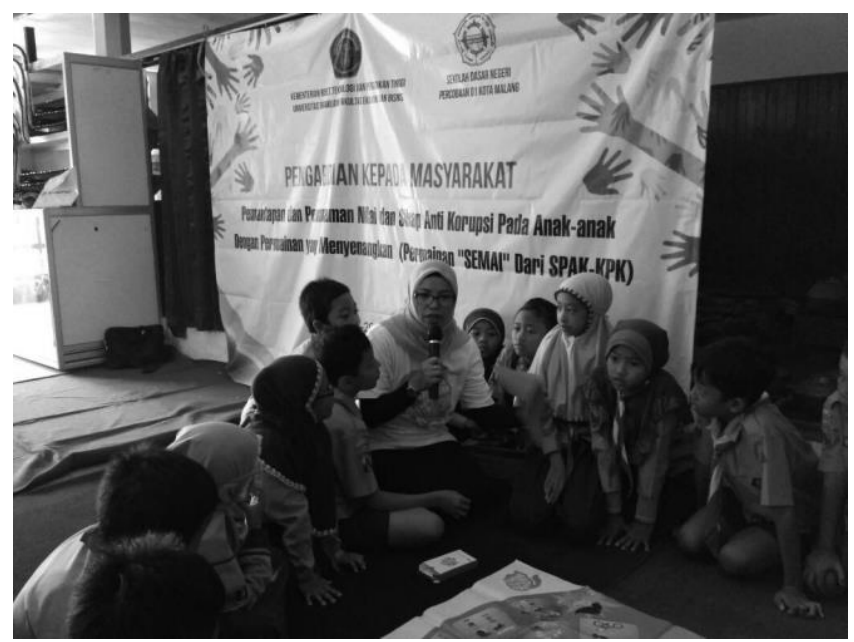

Gambar 3 Fasilitator memberikan arahan dan penilaian terhadap jawaban permainan SEMAI

Setelah peserta menentukan kategori kelompok nilai antikorupsi, tim lawan memberikan penilaian disertai alasan, apakah jawaban tersebut benar atau salah. Fasilitator yang bertugas kemudian memimpin diskusi tersebut dan memberikan keputusan. Disaat jawaban tersebut salah, peserta mengambil kartu merah dan menjawab pertanyaan atau melaksanakan perintah yang tertera di dalamnya. Hal tersebut kemudian terjadi seterusnya bergiliran. Kelompok yang menang ditentukan berdasarkan mereka yang paling banyak menempatkan kartu putih dan paling sedikit mengambil kartu merah. Para siswa mengikuti permainan ini dengan antusias dan bersemangat. Permainan ini terbukti dapat menarik minat siswa serta kompetisi yang sehat dengan teman-teman mereka. Didukung dengan fasilitator yang dapat mengendalikan kondisi siswa, bertanggungjawab, dan antusias, pelaksanaan "secara fisik" ini dapat terlaksana dengan lancar dan sesuai ekspektasi.

\section{Gambaran Pelaksanaan Kegiatan Non- Fisik Permainan SEMAI (SPAK-KPK)}

Setelah pelaksanaan "secara fisik", kegiatan ini diikuti dengan pelaksanaan "non fisik" berupa pengamatan perubahan perilaku anak-anak. Kegiatan ini dilakukan selama kurang lebih satu bulan dengan melibatkan peran serta guru kelas yang akan menjadi pihak yang melakukan pengamatan terhadap siswa. Setiap minggu, tim pengabdi melakukan upaya dialog dengan guru kelas yang sehari-hari berinteraksi dengan anak-anak tersebut, dalam tujuan untuk mengetahui perkembangan perilaku siswa setelah mereka dikenalkan dengan pengetahuan tentang korupsi dan melaksanakan permainan SEMAI yang menyenangkan. Setelah anak-anak yang melaksanakan permainan SEMAI, memahami nilai-nilai yang disebutkan di dalam permainan ini, tim pengabdi melihat apakah anak-anak dapat melaksanakan mengapliasikan nilai-nilai tersebut dalam kehidupan mereka sehari-hari, apakah sikap mereka dapat terlihat di dalam komunitasnya masing-masing dan dapat dikoordinasikan kembali untuk penyebarluasan nilai dan sikap antikorupsi. 


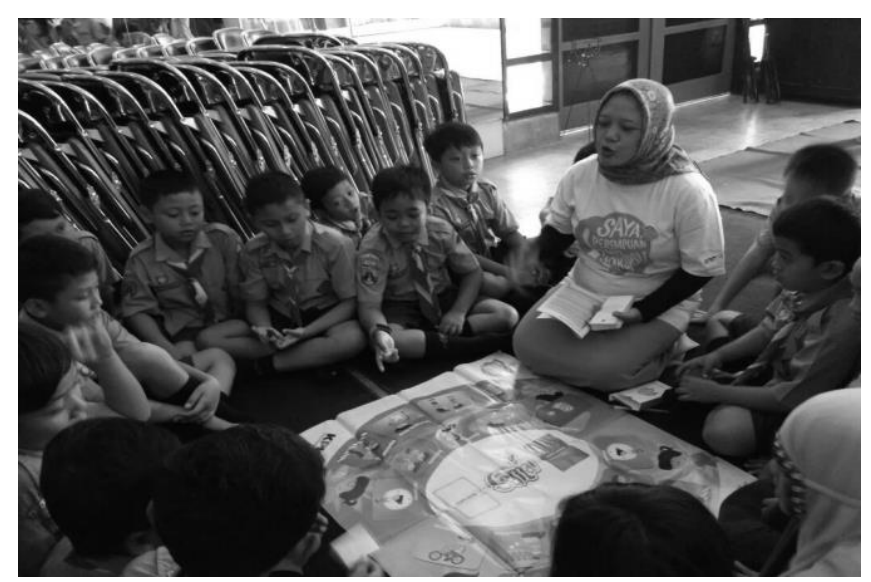

Gambar 4 Penjelasan agen SPAK tentang implementasi sembilan nilai

Salah satu hasil dari pengamatan yang dilakukan oleh guru kelas terlihat dalam kegiatan Jum'at Bersih. Jum'at Bersih adalah kegiatan membersihkan lingkungan sekolah dengan tujuan untuk memperindah dan membersihkan lingkungan. Setelah dilaksanakan permainan SEMAI, para siswa dapat melaksanakan kegiatan Jum'at Bersih tanpa pengawasan guru. Mereka membersihkan lingkungan sekolah dengan bekerjasama dengan sesama siswa dalam ketertiban, semangat, dan tanggungjawab hanya dengan koordinasi ketua kelas. Selain tanggung jawab dan kemandirian yang terlihat dalam kegiatan Jum'at Bersih, perubahan yang terjadi di para siswa terlihat dalam kegiatan konsumsi mereka. Anak-anak mengurangi jumlah jajanan yang mereka beli, sehingga hal ini menunjukkan bahwa mereka telah menerapkan sifat hemat, yaitu salah satu dari sembilan pin dalam SEMAI. Dampat dari sifat hemat ini sangat luas, hingga hal ini terlihat dalam jumlah uang amal yang mereka berikan dalam kegiatan Jum'at Berbagi. Jum'at Berbagi merupakan kegiatan dimana para siswa memberikan sebagian dari uang jajan mereka untuk didonasikan kepada anak yatim piatu. Setelah diadakan kegiatan permainan SEMAI, uang jajan yang biasanya mereka gunakan untuk makan, sebagian mereka donasikan di dalam Jum'at Berbagi, dan jumlahnya meningkat dibandingkan dengan sebelum mereka melaksanakan permainan SEMAI.

Dampak dari permainan ini juga terlihat dari berkurangnya jumlah siswa yang datang terlambat. Pengurangan ini menunjukkan bahwa para siswa telah memiliki kedisiplinan dan tanggungjawab yang lebih terhadap tugas mereka di sekolah dibandingkan dengan sebelum dilaksanakannya permainan SEMAI. Dampak yang signifikan juga terlihat disaat mereka melaksanakan ulangan harian, dimana guru dapat melihat bahwa semakin percaya diri dalam menjawab ulangan tersebut. Para siswa tidak bertanya kepada temannya atau bahkan melihat jawaban temannya. Hal ini menunjukkan fakta bahwa sikap kejujuran telah mulai tertanam di dalam diri mereka.

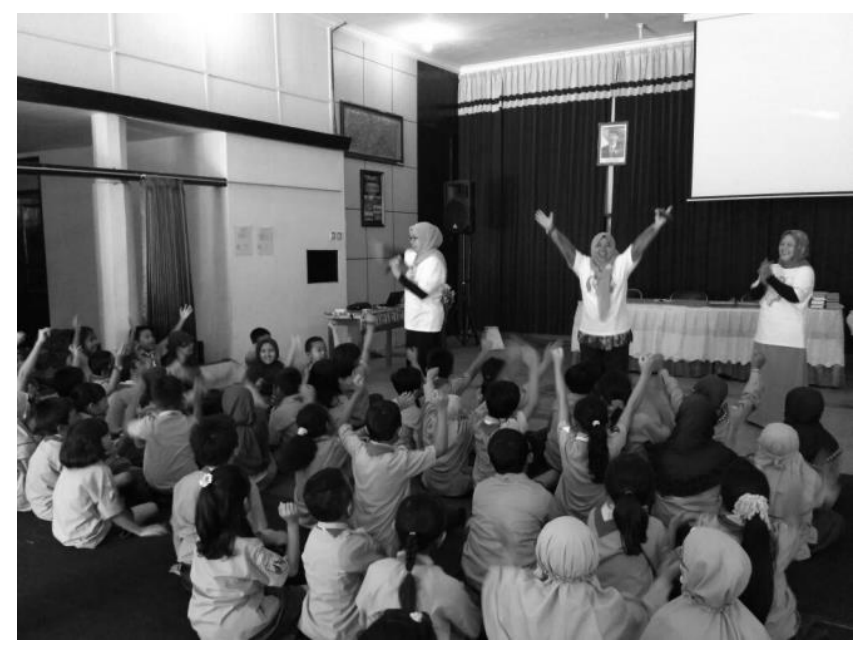

Gambar 5 Sesi penggalian ide tentang nilai moral

Dengan adanya perubahan dan dampak yang signifikan yang terlihat di dalam diri mereka, diharapkan pada gilirannya nilai dan sikap antikorupsi ini akan dikenal secara meluas oleh anak-anak dan mendukung gerakan yang lebih masif. SEMAI ini juga diharapkan untuk dapat menanamkan nilai inti anti 
korupsi yang selanjutnya dapat dikembangkan untuk pembentukan sikap anti korupsi. Dengan adanya pengenalan nilai-nilai anti korupsi melalui permainan yang menyenangkan ini maka diharapkan akan mampu memberikan wawasan yang akan berkembang dengan sikap sehari-hari yang dalam jangka panjang akan mampu mengubah kehidupan masyarakat syarat korupsi dengan kondisi masyarakat yang lebih bermartabat, bebas korupsi.

\section{KESIMPULAN}

Berdasarkan kegiatan pengabdian masyarakat di Desa Pandansari Kecamatan Poncokusumo Kabupaten Malang ini dapat disimpulkan bahwa sumber daya alam terutama perkebunan sudah tidak lagi memberikan hasil yang optimal akibat erusi gunung Bromo. Perkebunan apel banyak yang mati dan tanah sudah tidak lagi subur karena hanya mengandalkan air hujan. Berdasarkan analisis situasi bahwa mitra memiliki pengetahuan yang rendah tentang pengelolaan sumber daya alam, sehingga solusi yang ditawarkan adalah penyuluhan tentang pengelolaan sumber daya alam. Pengetahuan dan motivasi wirausaha juga masih rendah sehingga dilakukan sosialisasi dan motivasi wira usaha untuk mengantisipasi penurunan tingkat ekonomi pada masyarakat. Selanjutnya dilakukan pemilihan usaha bersama yang akan dibentuk oleh masyarakat khususnya pada kader ibu-ibu PKK. Usaha yang dikembangkan adalah usaha pengolahan kripik singkong dan kripik jamur tiram.

Hasil kegiatan menunjukkan bahwa mitra sudah dapat mengetahui dan memahami tentang pengelolaan sumber daya alam yang sesuai dengan skill masyarakat. Mitra pengabdian ini telah memperoleh penimgkatan wawasan tentang wirausaha serta telah dapat mengembangkan sebuah usaha bersama yaitu usaha kripik singkong dan kripik jamur. Disamping itu mitra dapat melakukan pembuatan produk dan dapat menganalisis kelayakan usaha.

Pelatihan dan pendampingan ini bertujuan untuk meningkatkan nilai dan sikap antikorupsi secara meluas oleh anak-anak dan mendukung gerakan yang lebih masif. Penanaman nilai inti anti korupsi yang selanjutnya dapat dikembangkan untuk pembentukan sikap anti korupsi juga merupakan tujuan jangka pangkang. Dengan adanya pengenalan nilai-nilai anti korupsi melalui permainan yang menyenangkan ini maka diharapkan akan mampu memberikan wawasan yang akan berkembang dengan sikap sehari-hari yang dalam jangka panjang akan mampu mengubah kehidupan masyarakat syarat korupsi dengan kondisi masyarakat yang lebih bermartabat, bebas korupsi. Dengan metode kegiatan yang dirancang dalam bentuk permainan dan dilanjutkan dengan pengamatan terhadap perubahan perilaku, dan kegiatan ini akan berdampak pada upaya menumbuhkan jiwa anti-korupsi, terutama melalui nilai-nilai SEMAI. Secara khusus, dampak positif seperti ini terbentuk pada siswa SD Negeri Percobaan 1 Kota Malang kelas 3 sebagai objek yang dituju pada kegiatan pengabdian kepada masyarakat ini. Perubahan perilaku ini terlihat dalam kemandirian dalam Jum'at Bersih, penghematan untuk konsumsi di sekolah, peningkatan amal yang dilaksanakan dalam Jum'at Berbagi, kedisiplinan yang terlihat dalam penurunan jumlah siswa yang terlambat, serta kepercayaan diri yang terlihat dalam kegiatan ulangan.

Pencegahan tindakan korupsi dapat dilaksanakan sejak dini. Pencegahan ini tentunya dapat diimplementasikan melalui permainan-permainan, namun tidak terbatas pada hal tersebut, pencegahan dapat dilaksanakan melalui berbagai kegiatan kreatif. Kegiatan ini merupakan perwujudan dari upaya ikut serta dalam pencegahan tindakan korupsi dan meningkatkan kepekaan terhadap sikap dan nilai anti korupsi sejak dini, sehingga perlu dilaksanakan kegiatan pemantapan dan sosialisasi sikap dan nilai ini terhadap anak-anak sejak dini.

\section{UCAPAN TERIMAKASIH}

Terima kasih kepada Fakultas Ekonomi \& Bisnis Universitas Brawijaya Malang atas bantuan pendanaan untuk terlaksananya penelitian ini dan siswa serta pihak terkait di SD Negeri Percobaan 1 Kota Malang kelas 3 atas kesediaannya untuk menjadi obyek penelitian serta dukungan selama penelitian.

\section{REFERENSI}

[1] Agung, I Gusti Ngurah, 1992, Metode Penelitian Sosial, Pengertian dan Pemakaian Praktis, Jilid 1, Penerbit PT. Gramedia Pustaka Utama, Jakarta 
[2] Arief, Sritua, 1993, Metodologi Penelitian Ekonomi, Cetakan Pertama, Penerbit Universitas Indonesia, Jakarta

[3] Handayani, Trisakti, 2002, Metode Penelitian Berperspektif Gender, Makalah Lokakarya Regional Penelitian Berperspektif Gender Perguruan Tinggi Muhammadiyah Se-Jawa dan Indonesia Timur, Pusat Studi Wanita dan Kemasyarakatan, Universitas Muhammadiyah Malang.

[4] Wijaya Hesti, 1992, Kemandirian Perempuan Indonesia, Kumpulan Makalah Lokakarya Citra Kemandirian Perempuan Indonesia, Kelompok Studi Wanita Pusat Penelitian Universitas Brawijaya Malang

[5] 2016. Semai Anti Korupsi Dapat MURI,

http://www.kpk.go.id/id/berita/berita-sub/2886-semai-anti-korupsi-dapat-muri, diakses pada tanggal 30 November 2016

[6] KPK Luncurkan Edukasi Anti Korupsi Untuk Anak Melalui Permainan, http://kabar24.bisnis.com/read/20150708/16/451401/kpk-luncurkan-edukasi-anti-korupsi-untuk-anakmelalui-permainan, diakses pada tanggal 30 November 2016

[7] Semai Nilai Anti Korupsi Dengan Permainan Anak

http://www.kpk.go.id/id/berita/siaran-pers/2795-semai-nilai-antikorupsi-dengan-permainan-anak, diakses pada tanggal 29 November 2016 
Pemantapan dan Penanaman Nilai dan Sikap Anti Korupsi ... (Badriyah) 